\title{
Ovarian Clear Cell Adenocarcinoma
}

National Cancer Institute

\section{Source}

National Cancer Institute. Ovarian Clear Cell Adenocarcinoma. NCI Thesaurus. Code C40078.

A malignant glandular epithelial neoplasm characterized by the presence of clear and hobnail cells. It is highly associated with ovarian endometriosis, pelvic endometriosis and paraendocrine hypercalcemia. 